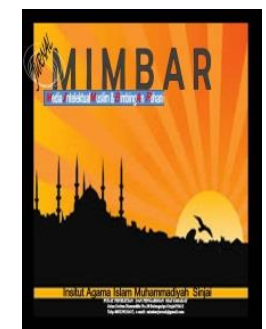

MIMBAR

Jurnal Media Intelektual Muslim dan Bimbingan Rohani

Volume 5, No. 2, 2019

ISSN (print) : 2442-3217

ISSN (online) : 2716-3806

Homepage : http://journal.iaimsinjai.ac.id/indeks.php/mimbar

\title{
KECERDASAN RUHANIAH DENGAN ALTRUISME (Studi Kasus Mahasiswa Program Studi Bimbingan Penyuluhan Islam di Staim Sinjai)
}

\author{
Rahmatullah ${ }^{1}$ \\ Institut Agama Islam Muhammadiyah Sinjai
}

\begin{abstract}
Abstrak
Seiring dengan kemajuan teknologi dan komunikasi pada saat ini semakin banyak individu yang mementingkan dirinya sendiri atau berkurangnya rasa tolong menolong antara sesama. Globalisasi juga berperan membuat hubungan antar sesama manusia menjadi semakin rumit. Kerumitan ini dapat menciptakan stress dan kekerasan-kekerasan yang kadang-kadang disebabkan oleh hal-hal sepele dan aneh. Semakin berkembangnya aktivitas pada setiap orang, maka akan semakin sibuk dengan urusannya sendiri, yang memunculkan sifat atau sikap individualisme yang menjadi ciri manusia modern. Individualisme ini merupakan faham yang bertitik tolak dari sikap egoisme, mementingkan dirinya sendiri, sehingga mengorbankan orang lain demi kepentingan dirinya sendiri. ${ }^{2}$
\end{abstract}

Kata kunci : Kecerdasan Rohani,Altruisme,Aspek-aspek kecerdasan

${ }^{1}$ Dosen Institut Agama Islam Muhammadiyah Sinjai

${ }^{2}$ I. LNH. Niken, Seni: Wahana untuk menajamkan rasa dan memintarkan emosinal, (Ed. III; Yogyakarta, 1998), h. 19. 


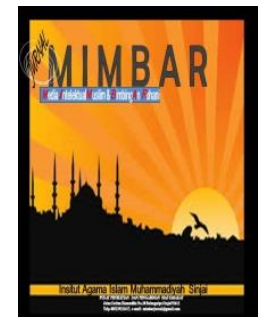

MIMBAR

Jurnal Media Intelektual Muslim dan Bimbingan Rohani

Volume 5, No. 2, 2019

ISSN (print) : 2442-3217

ISSN (online) : 2716-3806

Homepage : http://journal.iaimsinjai.ac.id/indeks.php/mimbar

\section{PENDAHULUAN}

\section{A. Latar Belakang Masalah}

Atas dasar kesatuan asal-usul dan kesamaan derajat dihadapan Allah SWT, tiap-tiap individu harus menyadari tanggung jawab yang telah ditentukan Allah. Tanggung jawab dapat diartikan berbagai macam, tapi yang paling penting adalah upaya untuk menciptakan kesejahteraan bersama dalam lingkungan masyarakat. Seseorang yang tergolong mampu secara fisik atau mampu secara harta maka dianjurkan untuk menolong orang yang tidak mampu. Sebaliknya seorang yang tidak mampu, misalnya, karena berusaha sehingga dapat dikatakan mampu, maka dia diajurkan juga untuk memberi bantuan kepada orang lain yang tidak mampu atau dalam kesusahan.

Setiap orang harus memahami fungsi masing-masing. Seorang muslim hendaklah mengunjungi saudara muslimnya yang sakit, meringankan beban orang yang mendapat kesulitan, menciptakan rasa cinta kasih, persaudaraan dan solidaritas antara satu dan lainya, ia juga hendaknya memberikan hak-hak orang sekelilingnya, seperti hak untuk mendapat kehidupan dan perlakuan yang layak. Islam menganjurkan, hendaklah diciptakan rasa kebersamaan dalam masyarakat dan saling membantu orang-orang yang sedang mengalami kesusahan, karena Allah menjanjikan pahala bagi orang-orang yang mau membantu sesama dengan iklash. ${ }^{3}$

Mengingat masih banyak orang-orang yang hidup didalam kesusahan dan membutuhkan pertolongan dan sebagian besar diantaranya adalah orang-orang yang beragama islam, maka menjadi sebuah kewajiban bagi umat islam untuk memberikan bantuan kepada orang-orang tersebut yaitu dhuafa, fuqara dan masakin atau orangorang yang sedang tertimpa musibah. Altruisme adalah tindakan menolong yang dilakukan seseorang dalam kondisi tertentu. Pada altruisme salah satu yang penting

$$
14 .
$$

${ }^{3}$ Jalaludin, Psikologi Agama, (Edisi revisi; Jakarta: PT. Raja Grafindo Persada, 2004), h. 
adalah sifat empati atau merasakan perasaan orang lain di sekitar kita. ${ }^{4}$ Hanya altruisme timbal balik yang mempunyai dasar biologis.

Kerugian potensial dari altruisme yang dialami individu diimbangi dengan kemungkinan menerima pertolongan dari individu lain. Beberapa ahli mengatakan bahwa altruisme merupakan bagian "sifat manusia" yang ditentukan secara genetika, karena keputusan untuk memberikan pertolongan melibatkan proses kondisi sosial komplek dalam mengambil keputusan yang rasional.

Dalam kehidupan sehari-hari banyak sekali fenomena masyarakat yang menunjukkan sikap altruisme diantaranya adalah seperti yang dilakukan oleh Rumah Sakit Harapan Bunda Jakarta. Satu-satunya rumah sakit yang mau menerima seorang anak dari pasangan Lila dan Husen yang telah ditolak oleh enam rumah sakit di Jakarta untuk berobat hanya karena keluarga itu miskin. ${ }^{5}$ Dalam kasus yang lain ketika terjadi gempa dan tsunami di Nangro Ace Darussalam, banyak sekali perusahaan besar, organisasi masyarakat, organisasi poloitik dan kelompok masyarakat lainnya yang memberi bantuan baik dalam bentuk uang atau barang.

Sebahagian diantara penyumbang melakukan konferensi pers untuk memperkenalkan diri dan memberitahukan jumlah atau pun bentuk sumbangan yang telah disalurkan. Terkhusus bagi penyumbang yang memperkenalkan diri melalui konferensi pers, menurut penulis mempunyai motif lain dibalik sumbangan yang disalurkan. Diberitakan dibeberapa media cetak dan elektronik bahwa ada sebahagian relawan pada saat tsunami di Aceh yang dibayar baru mau bekerja, dan sebagian mereka adalah para relawan yang berasal dari daerah sekitar Aceh itu sendiri. Bahkan ada sebagian relawan yang memanfaatkan kondisi Aceh saat itu dengan mengambil besi-besi bekas bangunan dan kendaraan-kendaraan yang terkena bencana tsunami dan gempa.

Penulis pun biasa mendengar bahwa ada kebiasaan mahasiswa dimana saatsaat ujian tengah semester maupun ujian akhir semester yaitu membantu dengan cara

\footnotetext{
${ }^{4}$ Hendri Rain Sus Budiharto, Hubungan antara kecerdasan ruhaniah dengan altruisme, (Yogyakarta: Universitas Islam Indonesia, 2005), h. 2.

${ }^{5}$ Harian Kompas, Peduli Sosial Rumah Sakit Merosot, (Jakarta: 1 Agustus 2005).
} 


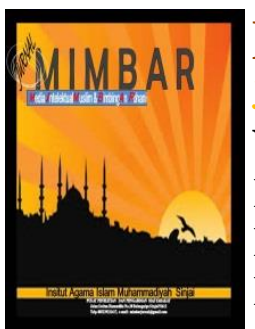

meminjamkan catatan untuk di foto copy oleh mahasiswa yang lain, bahkan ada kejadian mahasiswa lain yang membuatkan tugas untuk mahasiswa yang lain. Mengapa ada sebahagian diantara kita tak terkecuali dikalangan mahasiswa yang mengulurkan bantuan dengan cara yang tidak benar dan atau mengulurkan bantuan disertai dengan kepentingan kelompoknya maupun dirinya sendiri? Setinggi apakah kondisi kecerdasan Ruhaniah serta seberapa besar tingkat Altruisme yang telah tertanam didalam diri mereka? Itulah yang mendorong peneliti untuk melakukan penelitian ini.

Pada kecerdasan spiritual yang digagas oleh Zohar dan Marshall, menerangkan bahwa:

Kecerdasan spiritual memungkinkan manusia menjadi kreatif, kecerdasan spritual memungkinkan kita untuk bermain dengan batasan, memainkan "permainan tak terbatas". Kecerdasan spiritual memberikan kemampuan kepada kita untuk membedakan, memberikan rasa moral, kemampuan menyesuaikan aturan yang kaku dibarengi dengan pemahaman dan cinta serta kemapuan setara untuk melihat kapan cinta dan pemahaman sampai pada batasnya. Kecerdasan spiritual digunakan untuk bergulat dengan ihwal baik dan jahat, serta untuk membayangkan kemungkinan yang belum terwujud untuk bermimpi, bercita-cita, dan mengangkat diri dari kerendahan. ${ }^{6}$

Penelitian ini sangat penting untuk dilakukan karena sebagian orang ada yang memberikan bantuan pada orang lain tampa memperdulikan resiko yang akan dihadapinya, tapi dilain pihak ada juga orang yang sanggat tidak perduli pada kesusahan orang lain. Maka penelitian ini dilakukan dengan tujuan untuk mendapatkan pemahaman yang lebih jelas tentang antara hubungan kecerdasan ruhaniah yang dikaitkan dengan altruisme. Untuk mendapatkan jawaban yang tepat perlu dibuktikan dalam suatu penelitian ilmiah, yang akan dituangkan dalam tulisan dengan judul "Hubungan Antara Kecerdasan Ruhaniah dengan Altruisme pada Mahasiswa Program Studi Bimbingan Penyuluhan Islam STAIM Sinjai”.

${ }^{6}$ D. Zohar \& Marshall, SQ: Manfaat Kecerdasan Spiritual Dalam Berpikir Integralistik dan Holistik Untuk Memaknai Kehidupan. (Bandung: Mizan, 2001), h. 35. 
Volume 5, No. 2, 2019

ISSN (print) : 2442-3217

ISSN (online) : 2716-3806

Homepage : http://journal.iaimsinjai.ac.id/indeks.php/mimbar

\section{B. Rumusan dan Batasan Masalah}

\section{Rumusan Masalah}

Rumusan masalah dimaksudkan sebagai penegasan atas masalah pokok yang akan dikaji, diformulasikan dalam bentuk pertanyaan penelitian (research question). Adapun rumusan masalah dalam penelitian ini adalah :

a. Bagaimana hubungan kecerdasan ruhaniah dengan altruisme pada mahasiswa program studi Bimbingan Penyuluhan Islam di STAIM Sinjai?

b. Bagaimana kecerdasan ruhaniah mempengaruhi atruisme pada mahasiswa program studi Bimbingan Penyuluhan Islam di STAIM Sinjai?

\section{PEMBAHASAN}

\section{A. Tinjauan Kecerdasan Ruhaniah}

\section{Pengertian Kecerdasan Ruhaniah}

Kecerdasan ruhaniah adalah sebuah dimensi yang tidak kalah pentingnya didalam kehidupan manusia bila dibandingkan dengan kecerdasan emosional, karena kecerdasan emosional lebih berpusat pada rekonstruksi hubungan yang bersifat horizontal (sosial), sementara itu dimensi kecerdasan ruhaniah bersifat vertikal yang sering disebut dengan kecerdasan ruhaniah (Spiritual Quotient) ${ }^{7}$

Lebih lanjut diterangkan Zohar dan Marshall mendefinisikan kecerdasan ruhaniah adalah spiritual untuk menghadapi persoalan makna atau value, yaitu kecerdasan inti menempatkan perilaku dan hidup kita dalam konteks makna yang lebih luas dan lebih kaya, kecerdasan untuk menilai bahwa tindakan atau jalan hidup seseorang lebih bermakna dibandingkan dengan yang lain. ${ }^{8}$ Kecerdasan ruhaniah adalah landasan yang diperlukan untuk memfungsikan IQ dan EQ secara efektif, bahkan kecerdasan spiritual merupakan kecerdasan tertinggi manusia.

${ }^{7}$ D. Zohar \& Marshall, SQ: Manfaat Kecerdasan Spiritual Dalam Berpikir Integralistik dan Holistik Untuk Memaknai Kehidupan. (Bandung: Mizan, 2001). H. 38.

${ }^{8}$ Ibid., h. 39. 


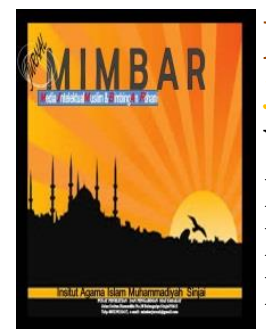

MIMBAR

Jurnal Media Intelektual Muslim dan Bimbingan Rohani

Volume 5, No. 2, 2019

ISSN (print) : 2442-3217

ISSN (online) : 2716-3806

Homepage : http://journal.iaimsinjai.ac.id/indeks.php/mimbar

Agama dalam kehidupa individu berfungsi sebagai suatu sistem nilai yang memuat norma-norma tertentu. Secara umum norma-norma tersebut menjadi kerangka acuan dalam bersikap dan bertingkah laku agar sejalan dengan keyakinan agama yang dianutnya. ${ }^{9}$

Dalam ajaran agama Islam bahwa adanya kebutuhan terhadap agama disebabkan manusia selaku mahluk tuhan yang dibekali dengan berbagai potensi (fitrah) yang dibawa sejak lahir. Salah satu fitrah manusia itu adalah kecenderungan terhadap agama, firman Allah SWT dalam QS. Ar-Rum (30): 30.

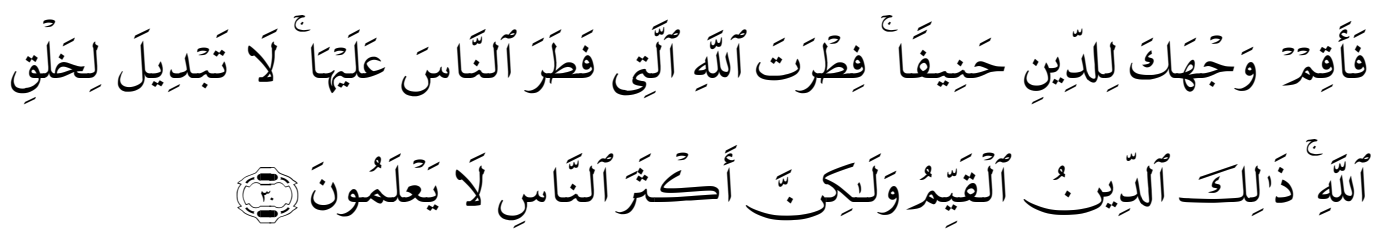

Terjemahan :

Maka hadapkanlah wajahmu dengan Lurus kepada agama Allah; (tetaplah atas) fitrah Allah yang telah menciptakan manusia menurut fitrah itu. Tidak ada peubahan pada fitrah Allah. (Itulah) agama yang lurus; tetapi kebanyakan manusia tidak mengetahui. ${ }^{10}$

Fitrah Allah maksudnya adalah ciptaan Allah. manusia diciptakan Allah mempunyai naluri beragama yaitu agama tauhid. Kalau ada manusia tidak beragama tauhid, maka hal itu tidaklah wajar. Mereka tidak beragama tauhid itu hanyalah lantara pengaruh lingkungan. ${ }^{11}$ Laggulung sebagai mana yang dikutib oleh Hendri Rain Sus Budiharto, dalam tulisannya "Hubungan antara kecerdasan ruhaniah dengan altruisme mengatakan :

${ }^{9}$ Jalaludin, Psikologi Agama, (Edisi revisi, Cet. 13; Jakarta : PT. Raja Grafindo Persada, 2010), h. 318.

${ }^{10}$ Departemen Agama RI, Al-Qur'an dan Terjemahannya, (Ed. Khat Madinah; Bandung: Syamil Cipta Media, 2005), h. 412.

${ }^{11}$ Ibid. 


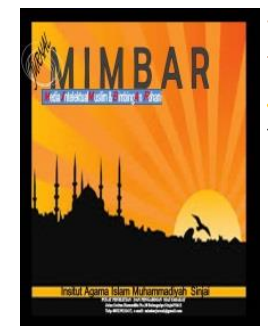

Volume 5, No. 2, 2019

ISSN (print) : 2442-3217

ISSN (online) : 2716-3806

Homepage : http://journal.iaimsinjai.ac.id/indeks.php/mimbar

Salah satu ciri fitrah ini adalah, bahwa manusia menerima Allah sebagai tuhan, dengan kata lain, manusia itu adalah dari asal mempunyai kecenderungan beragama, sebab agama itu sebagian dari fitrah-Nya. ${ }^{12}$

Kecerdasan ruhaniah sangat erat kaitannya dengan cara dirinya mempertahankan prinsip lalu bertanggung jawab untuk melaksanakan prinsipprinsipnya itu dengan tetap menjaga keseimbangan dan melahirkan nilai manfaat yang berkesesuaian. Prinsip merupakan fitrah paling mendasar bagi harga diri manusia. Nilai takwa atau tanggung jawab merupakan ciri seorang profesional. Mereka melangar prinsip dan menodai hati nurani merupakan dosa kemanusiaan yang paling ironis. ${ }^{13}$

Kecerdasan ruhaniah adalah kecerdasan yang paling sejati tentang kearifan dan kebenaran serta pengetahuan Ilahi. Kecerdasan ini dapat menimbulkan kebenaran yang sanggat mendalam terhadap kebenaran, sedangkan kecerdasan lainya lebih bersifat pada kemampuan untuk mengelola segala hal yang berkaitan dengan bentuk lahiriah (duniawi). ${ }^{14}$ Oleh karena itulah, dapat dikatakan bahwa setiap niat yang terlepas dari nilai-nilai kebenaran Ilahiah, merupakan kecerdasan duniawi dan fana (temporer), sedangkan kecerdasan ruhaniah qabliyah bersifat autentik, universal, dan abadi, kecerdasan ruhaniah merupakan inti dari seluruh kecerdasan yang dimilki manusia karena kecerdasan ruhaniah dapat mempengaruhi perkembangan beberapa beberapa kecerdasan yang lain diantranya yaitu:
a. Kecerdasan Intlektual.
b. Kecerdasan Emosional.
c. Kecerdasan Sosial.
d. Kecerdasan Physical. ${ }^{15}$

\footnotetext{
${ }^{12}$ Hendri Rain Sus Budiharto, Hubungan antara kecerdasan ruhaniah dengan altruisme, (Yogyakarta: Universitas Islam Indonesia, 2005), h. 56. 2001), h. 38 .

${ }^{13}$ T. Tasmara, Kecerdasan Ruhania: Transendental Intellgensi, (Jakarta: Gema Insani,

${ }^{14}$ Ibid. h. 40.

${ }^{15}$ Ibid. h. 41
} 


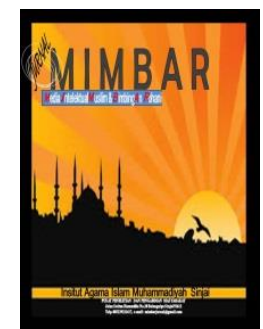

MIMBAR

Jurnal Media Intelektual Muslim dan Bimbingan Rohani

Volume 5, No. 2, 2019

ISSN (print) : 2442-3217

ISSN (online) : 2716-3806

Homepage : http://journal.iaimsinjai.ac.id/indeks.php/mimbar

\section{Aspek-aspek Kecerdasan Ruhaniah}

a. Shiddiq

Salah satu dimensi kecerdasan ruhaniah terletak pada nilai kejujuran yang merupakan mahkota kepribadian orang-orang mulia yang telah dijanjikan Allah akan memperoleh limpahan nikmat dari-Nya. Seseorang yang cerdas secara ruhaniah, senantiasa memotivasi dirinya dan berada dalam lingkungan orang-orang yang memberikan makna kejujuran, sebagai mana firman Allah dalam QS. At-Taubah (9): 119.

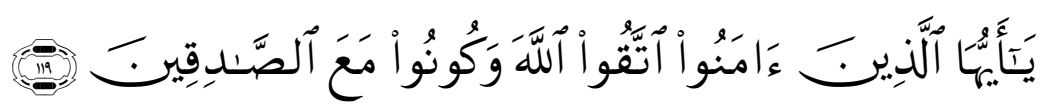

Terjemahan :

Hai orang-orang yang beriman, bertakwalah kepada Allah dan hendaklah kamu bersama orang-orang yang benar (jujur). ${ }^{16}$

Shiddiq adalah orang benar dalam semua kata, perbuatan, dan keadaan batinya. Hati nuraninya menjadi bagian dari kekuatan dirinya karena dia sadar bahwa segala hal yang akan mengganggu ketentraman jiwanya merupakan dosa. Dengan demikian, kejujuran bukan datang dari luar, tetapi ia adalah bisikan dari qalbu yang secara terus menerus mengetuk-ngetuk dan memberikan percikan cahaya Ilahi. Ia merupakan bisikan moral luhur yang didorong dari hati menuju kepada Ilahi (mahabbah lilllah). Kejujuran bukan sebuah keterpaksaan, melainkan sebuah pangilan dari dalam (calling from withim) dan sebuah keterikatan.

Perilaku yang jujur adalah prilaku yang diikuti dengan sikap tanggung jawab atas apa yang diperbuatnya, karena dia tidak pernah berfikir untuk melemparkan tanggung jawab kepada orang lain, sebap sikap tidak bertanggung jawab merupakan pelecehan paling azasi terhadap orang lain, serta sekaligus penghinaan terhadap dirinya sendiri. Kejujuran dan rasa tanggung jawab yang

${ }^{16}$ Departemen Agama RI, Al-Qur'an dan Terjemahannya, h. 206. 


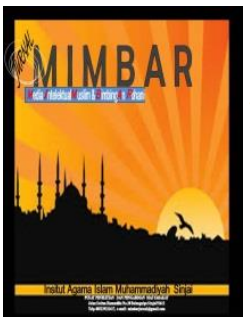

MIMBAR

Jurnal Media Intelektual Muslim dan Bimbingan Rohani

Volume 5, No. 2, 2019

ISSN (print) : 2442-3217

ISSN (online) : 2716-3806

Homepage : http://journal.iaimsinjai.ac.id/indeks.php/mimbar

memancar dari qalbu, merupakan sikap sejati manusia yang bersifat universal, sehingga harus menjadi keyakinan dan jati diri serta sikapnya yang paling otentik, asli, dan tidak bermuatan kepentingan lain, kecuali ingin memberikan keluhuran makna hidup. Dalam usaha untuk mencapai sifat Shiddiq seseorang harus melalui beberapa hal diantranya adalah :

1) Jujur pada diri sendiri. Salah satu contoh jujur pada diri sendiri adalah pada saat seseorang melakukan sholat, begitu taat dan bersungguh-sungguh untuk mengikuti seluruh proses sejak dari takbir sampai salam, sholat ritual telah melahirkan nuansa kejujuran dan melaksanakan seluruh kewajiban dengan penuh tanggung jawab, bagi orang-orang yang shiddiq, esensi sholat tidak berhenti sampai ucapan assalamu'alaikum, tetapi justru ucapan itu merupakan awal bagi dirinya untuk membuktikan hasil sholatnya dalam kehidupan secara aktual dan penuh makna manfaat.

2) Jujur pada orang lain. Sikap jujur pada orang lain berarti sanggat prihatin melihat penderitaan yang dialami oleh mereka. Sehingga, seseorang yang shiddiq mempunyai sikap dan mempunyai jiwa pelayanan yang prima (sense of steweardship). Maka, tidak mungkin seseorang merasa gelisa berada bersamasama dengan kaum shiddiqin karena mereka adalah sebaik-baiknya teman yang penyantun dan penyayang serta direkomendasikan Allah. Tidak mungkin para shiddiqiin itu akan mencelakakan orang lain karena didalam jiwanya hanya ada kepedulian yang amat sanggat untuk memberikan kebaikan.

3) Jujur terhadap Allah. Jujur terhadap Allah berarti berbuat dan memberikan segala-galanya atau beribadah hanya untuk Allah, hal ini sebagaimana didalam doa iftitah, seluruh umat islam menyatakan ikrarnya bahwa sesungguhnya sholat, pengorbanan, hidup, dan mati mereka hanya diabadikan kepada Allah Yang Mahamulia, penyataan ini merupakan komitmen yang secara terusmenerus harus diperjuangkannya agar tidak keluar atau menyimpang dari arah yang sebenarnya. Itulah sebabnya didalam Al-Qur'an banyak ditemukan kata 
Volume 5, No. 2, 2019

ISSN (print) : 2442-3217

ISSN (online) : 2716-3806

Homepage : http://journal.iaimsinjai.ac.id/indeks.php/mimbar

shirath, syai'ah, thariqah, sabil, dan minhaj, yang semuanya memberikan makna dasar "jalan".

4) Menyebarkan salam. Salam tidak hanya memberikan pengertian selamat, tetapi mempunyai kandungan bebas dari segala ketergantungan dan tekanan, sehingga hidupnya terasa damai, tenteram dan selamat, karena itu setiap muslim akan mengucapkan salam setiap akhir sholat, seakan-akan mereka ingin membuktikan bahwa hasil audensinya dengan Allah akan dinyatakannyan secara nyata dan aktual dalam kehidupnya. ${ }^{17}$ Dengan demikian, makna salam merupakan benang merah dan indentitas paling monumental yang menjadi misi dan hiasan kepribadian serta sikap dan prilaku seorang muslim.

b. Istiqamah

Istiqamah diterjemahkan sebagai bentuk kualitas batin yang melahirkan sikap konsisten (taat azas) dan teguh pendirian untuk menegakkan dan membentuk sesuatu menuju pada kesempurnaan atau kondisi yang lebih baik, sebagai mana kata taqwin merujuk pula pada bentuk yang sempurna (qiwam). QS. Huud (11): 112

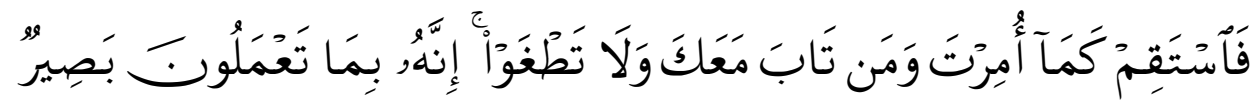

Terjemahan :

Maka tetaplah (istiqamalah) kamu pada jalan yang benar, sebagaimana diperintahkan kepadamu dan (juga) orang yang telah taubat beserta kamu dan janganlah kamu melampaui batas. Sesungguhnya Dia Maha melihat apa yang kamu kerjakan. ${ }^{18}$

Abu Ali ad-Daqqaq berkata ada tiga derajat pengertian istiqamah, yaitu menegakkan atau membentuk sesuatu (taqwim), menyehatkan dan meluruskan (iqamah), dan berlaku lurus (istiqamah), takwim menyangkut disiplin jiwa, Iqamah

\footnotetext{
${ }^{17}$ Hendri Rain Sus Budiharto, Hubungan Antara Kecerdasan Ruhaniah dengan Altruisme,
} h. 52 .

${ }^{18}$ Departemen Agama RI, Al-Qur'an dan Terjemahannya, h. 234 


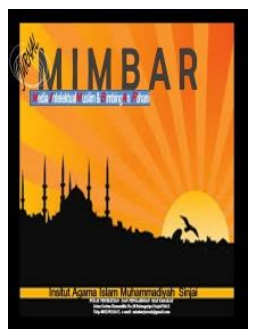

MIMBAR

Jurnal Media Intelektual Muslim dan Bimbingan Rohani

Volume 5, No. 2, 2019

ISSN (print) : 2442-3217

ISSN (online) : 2716-3806

Homepage : http://journal.iaimsinjai.ac.id/indeks.php/mimbar

berkaitan dengan penyempurnaan, dan istiqamah berhubungan dengan tindakan pendekatan diri kepada Allah. ${ }^{19}$

Sikap istiqamah menunjukkan kekuatan iman yang merasuki seluruh jiwanya, sehingga dia tidak mudah goncang atau cepat menyerah pada tantangan atau tekanan, mereka yang memiliki jiwa istiqamah itu adalah tipe manusia yang merasakan ketenanggan luar biasa (iman, aman, muthmainah) walau penampakannya diluar bagai orang yang gelisah. Dia merasa tenteram karena apa yang dia lakukan merupakan rangkaian ibadah sebagai bukti “yakin” kepada Allah Swt. dan RasulNya. Sikap istiqamah ini dapat terlihat pada orang-orang :

1) Mempunyai Tujuan. Sikap istiqamah hanya mungkin merasuki jiwa seseorang bila mereka mempunyai tujuan atau ada sesuatu yang ingin dicapai. Mereka mempunyai visi yang jelas dan dihayatinya sebagai penuh kebermaknaan, mereka pun sadar bahwa pencapaian tujuan tidaklah datang begitu saja, melainkan harus diperjuangkan dengan penuh dengan kesabaran, kebijakan, kewaspadaan, dan perbuatan yang memberikan kebaikan semata. Orang yang memilki sifat istiqamah akan tampak dari kretivitasnya, yaitu kemampuan untuk mengahasilkan sesuatu melalui gagasan-gagasannya yang segar, mereka mampu melakukan deteksi dini terhadap permasalahan yang dihadapinya, haus akan imformasi, dan mempunyai rasa ingin tahu yang besar (curiousity) serta tidak takut pada kegagalan.

2) Menghargai Waktu. Waktu adalah aset Ilahiyah yang paling berharga, bahkan merupakan kehidupan itu yang tidak dapat disia-siakan, Sungguh benar apa yang difirmankan Allah agar kita memperhatikan waktu.

3) Sabar. Sabar merupakan suasana baitn yang tetap tabah, istiqamah pada awal dan akhir ketika menghadapi tantangan, dan mengemban tugas dengan hati yang tabah dan optimis, sehingga dalam jiwa orang yang sabar tersebut terkandung beberapa hal yang diantaranya sebagai berikut, menerima dan menghadapi

19 Abu Ali ad-Daqqaq dikutip oleh T. Tasmara, Kecerdasan Ruhania: Transendental Intellgensi, (Jakarta: Gema Insani, 2001), h. 44. 


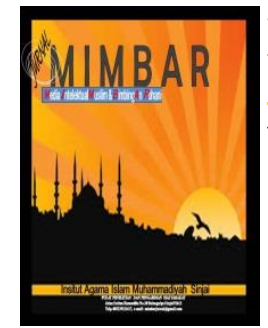

Volume 5, No. 2, 2019

ISSN (print) : 2442-3217

ISSN (online) : 2716-3806

Homepage : http://journal.iaimsinjai.ac.id/indeks.php/mimbar

tantangan dengan tetap konsisten dan berpengharapan, berkeyakinan Allah tidak akan memberikan beban diluar kemampuanya. Mereka tetap mengendalikan dirinya dan mampu melihat sesuatu dalam perspektif yang luas, tidak hanya melihat apa yang tampak, tetapi melihat sesuatu dalam kaitanya dengan yang lain. $^{20}$

4) Fathanah. Fathanah diartikan sebagai kemahiran, atau penguasaan terhadap bidang tertentu, pada hal makna fathanah merujuk pada dimensi mental yang sanggat mendasar dan menyeluruh. Seorang yang memilki sikap fathanah, tidak hanya menguasai bidangnya saja begitu juga dengan bidang-bidang yang lain, Keputusan-keputusanya menunjukkan warna kemahiran seorang profesional yang didasarkan pada sikap moral atau akhlak yang luhur, memilki kebijaksanaan, atau kearifan dalam berpikir dan bertindak.

5) Amanah. Amanah menjadi salah satu dari aspek dari ruhaniah bagi kehidupan manusia, seperti halnya agama dan amanah yang dipikulkan Allah menjadi titik awal dalam perjalanan manusia menuju sebuah janji. Janji untuk dipertemukan dengan Allah SWT, dalam hal ini manusia dipertemukan dengan dua dinding yang harus dihadapi secara sama dan seimbang antara dinding jama'ah didunia dan dinding kewajiban insan diakhirat nanti. Sebagai mahluk yang paling sempurna dari ciptaan Allah SWT dibandingkan dengan mahluk yang lain, maka amanah salah satu sifat yang dimilki oleh manusia sebagai khalifah dimuka bumi. $^{21}$ Didalam nilai diri yang amanah itu ada beberapa nilai yang melekat :

a. Rasa ingin menunjukkan hasil yang optimal.

b. Mereka merasakan bahwa hidupnya memiliki nilai, ada sesuatu yang penting. Mereka merasa dikejar dan mengejar sesuatu agar dapat menyelesaikan amanahnya dengan sebaik-baiknya.

${ }^{20}$ Hendri Rain Sus Budiharto, Hubungan antara kecerdasan ruhaniah dengan altruisme, $\mathrm{h}$. 57.

${ }^{21}$ Ibid., h. 58. 


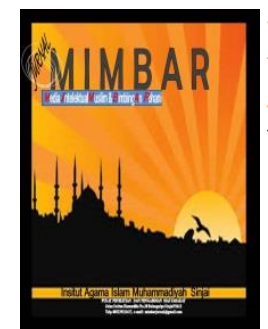

c. Hidup adalah sebuah proses untuk saling mempercayai dan dipercayai.

6) Tabligh. Fitrah manusia sejak kelahiranya adalah kebutuhan dirinya kepada orang lain. Kita tidak mungkin dapat berkembang kecuali ada kehadiran orang lain. Seorang muslim tidak mungkin bersikap egois atau annaniyah hanya mementingkan dirinya sendiri. Bahkan tidak mungkin mensucikan dirinya tanpa berupaya untuk menyucikan orang lain. Kehadirannya di tengah-tengah pergaulan harus memberikan makna bagi orang lain bagaikan pelita yang berbinar memberi cahaya terang bagi mereka yang kegelapan. ${ }^{22}$ Mereka yang memilki sifat tabligh mampu membaca suasana hati orang lain dan berbicara dengan kerangka pengalaman serta lebih banyak belajar dari pengalaman dalam menghadapi persoalan-persoalan hidup.

Berdasarkan keenam aspek-aspek kecerdasan ruhaniah diatas maka peneliti dapat membuat kesimpulan, bahwa kecerdasan ruhaniah adalah kemampuan atau kapasistas seseorang untuk pengunaan nilai-nilai agama baik dalam berhubungan secara vertikal atau hubungan dengan Allah Swt dan hubungan secara horizontal atau hubungan sesama manusia. Dengan arti kata lain kecerdasan spritual dimana kondisi seseorang yang telah dapat mendengar suara hati, karena pada dasarnya suara hati manusia masih bersifat universal, tapi apa bila seseorang telah mampu memunculkan beberapa sifat-sifat dari Allah yang telah diberikan-Nya kepada setiap jiwa manusia dalam bentuk yang fitrah dan suci yang disebut dengan asmaul khusna maka akan memunculakan sifat takwa.

\section{B. Tinjauan Altruisme}

\section{Pengertian Altruisme}

Perilaku altruistik adalah perilaku menolong yang timbul bukan karena adanya tekanan atau kewajiban, melainkan tindakan tersebut bersifat suka rela dan tidak berdasarkan norma-norma tertentu, tindakan tersebut juga merugikan penolong,

${ }^{22}$ Ibid., h. 59. 


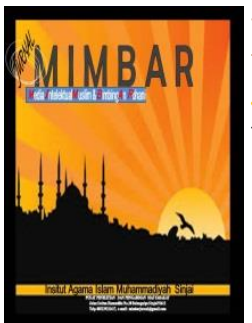

MIMBAR

Jurnal Media Intelektual Muslim dan Bimbingan Rohani

Volume 5, No. 2, 2019

ISSN (print) : 2442-3217

ISSN (online) : 2716-3806

Homepage : http://journal.iaimsinjai.ac.id/indeks.php/mimbar

karena meminta pengorbanan waktu, usaha, uang dan tidak ada imbalan atau pun reward dari semua pengorbanan. ${ }^{23}$

Definisi lain menyebutkan bahwa altruisme adalah tindakan suka rela yang dilakukan oleh seseorang atau pun kelompok orang untuk menolong orang lain tampa mengharapkan imbalan apa pun, kecuali mungkin perasaan telah melakukan perbuatan baik. ${ }^{24}$ Dengan defenisi ini, apakah suatu tindakan altuistik atau tidak, tergantung pada tujuan penolong, orang yang tidak dikenal mempertaruhkan nyawanya sendiri untuk menolong korban dari mobil yang terbakar, dan menghilang begitu saja, merupakan tindakan altruistik, lebih lanjut dijelaskan perilaku altruistik adalah salah satu dari sisi sifat manusia dengan rela untuk berbuat sesuatu untuk orang lain, tanpa berharap mendapatkan imbalan apa pun, sebaliknya egoisme mengunakan kepentingan sendiri diatas kepentingan orang lain untuk mengejar kesenagan.

Ajaran Islam altruisme merupakan tindakan untuk menolong orang lain secara ikhlas karena islam menilai kebaikan dan perbuatan seseorang berdasarkan keiklasan untuk mengharapkan ridho Allah swt, sehingga setiap amal yang dilakukan hanya semata-mata karena Allah swt, menafkahkan harta ditetapkan sebagai perbuatan baik, dan berpahala besar sebap sanggat bermanfaat untuk orang banyak, tindakan yang dilakukan seperti ini merupakan manifestasi dari bentuk kesolehan sosial. $^{25}$

Setiap muslim harus berusaha memberikan kontribusi dan peran nyata yang bermanfaat sehingga menjadikan kehidupan di dalam masyarakat sebagai kesempatan untuk mengaktualisasikan diri. Sebagai mahluk sosial, seorang muslim diperintahkan untuk memberikan pertolongan dan bantuan kepada sesama. Menurut

${ }^{23}$ Menurut Walstern dan Piliavin dikutib dari Hendri Rain Sus Budiharto, Hubungan antara kecerdasan ruhaniah dengan altruisme, (Yogyakarta: Universitas Islam Indonesia, 2005), h. 10.

${ }^{24}$ Taylor Sears. Et.al, Social Psychology, Tenth Edition. (New Jersey; Prentice-Hall Inc, 1994), h. 37. dikutib dari Hendri Rain Sus Budiharto, Hubungan antara kecerdasan ruhaniah dengan altruisme, $\mathrm{h} 14$.

${ }^{25}$ T. Tasmara, Kecerdasan Ruhania: Transendental Intellgensi, (Jakarta: Gema Insani, 2001), h. 32. 
Staub bahwa suatu tindakan yang dapat dikatakan altruisme apa bila memenuhi tiga kriteria yaitu:

a. Hasilnya baik bagi penolong maupun yang ditolong

b. Tindakan tersebut dilakukan secara sukarela tindakan tersebut dilakukan atas dasar empati bukan karena paksaan

c. Tindakan itu bukan untuk kepentingan diri sendiri, karena tindakan tersebut mengandung resiko tinggi pelaku, pelaku tidak mengharapkan imbalan materi, tidak untuk memperoleh persahabatan dan keintiman. ${ }^{26}$

Penulis menyimpulkan bahwa prilaku altruisme adalah tindakan yang diberikankan atau ditujukan pada orang lain dan memberi manfaat secara positif bagi orang tersebut yang dilakukan secara suka rela tampa mengharapkan imbalan apa pun, atau hanya sekedar untuk persahabatan, sikap ini tidak berdasarkan tekanan atau norma yang terkadang membutuhkan pengorbanan bagi sipenolong.

\section{Aspek-aspek Altruisme}

Aspek-aspek altruisme, mengacu pada pendapat Staub yang menyatakan bahwa dalam altruisme terdiri dari tiga hal yaitu:

a. Perilaku memberi

Perilaku ini bersifat menguntungkan bagi orang lain yang mendapat atau yang dikenai perlakuan dengan tujuan memenuhi kebutuhan atau keinginan orang lain, perilaku ini dapat berupa barang atau yang lainya.Pada mahasiswa misalnya memberikan bantuan pada mahasiswa yang lain saat mengerjakan tugas salah satu matakuliah

b. Empati

Empati merupakan kemampuan untuk mengetahui perasaan orang lain dan ikut berperan dalam pergulatan di arena kehidupan, kesadaran terhadap perasaan kebutuhan dan kepentingan orang lain, ciri empati yang tinggi adalah; memahami orang lain dengan minat aktif terhadap kepentingan mereka, orientasi pelayanan,

${ }^{26}$ E. Staub, Positive Sosial Behavior And Morality, (Vol. 1; New York: Academic Press, 1978), h. 47, Dikutib dari Hendri Rain Sus Budiharto, Hubungan antara kecerdasan ruhaniah dengan altruisme, h. 38. 


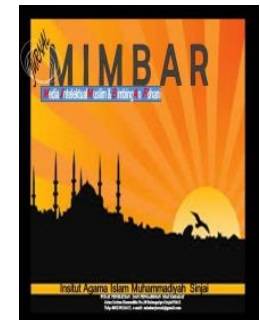

MIMBAR

Jurnal Media Intelektual Muslim dan Bimbingan Rohani

Volume 5, No. 2, 2019

ISSN (print) : 2442-3217

ISSN (online) : 2716-3806

Homepage : http://journal.iaimsinjai.ac.id/indeks.php/mimbar

mengembangkan orang lain, dan menumbuh kembangkankan hubungan saling percaya.

Empati membutuhkan cukup banyak ketenangan dan kesediaan untuk menerima, sehingga sinyal-sinyal perasaan halus dari orang lain dapat diterima dan ditirukan oleh otak emosional orang itu sendiri. Mahasiswa yang memiliki empati tinggi maka mahasiswa tersebut akan lebih mudah untuk ikut merasakan apa yang dirasakan oleh orang lain.

c. Suka Rela

Tidak adanya keinginan untuk mendapatkan imbalan apapun kecuali semata-semata dilakukan untuk kepentingan orang lain. ${ }^{27}$ Misalnya mahasiswa yang menjadi panitia pada sebuah acara yang dilaksanakan oleh perguruan tinggi.

\section{Faktor-faktor Yang Mempengaruhi Altruisme}

Dirangkum dari beberapa pendapat, menurut Hendri Rain S. Budiharto, ada 8 faktor yang mempengaruhi altruisme:

\section{Faktor Kepribadian}

Orang yang mempunyai tingkat kebutuhan yang tinggi untuk diterima secara sosial, lebih cenderung menyumbangkan uang bagi kepentingan amal dari pada orang yang mempunyai tingkat kebutuhan rendah untuk diterima secara sosial, tetapi hanya bila orang lain menyaksikan.

\section{Faktor Personal dan Situasional}

Faktor personal dan situasional sangat mungkin berpengaruh dalam perilaku menolong, seseorang lebih suka menolong orang yang disukainya, memiliki kesamaan dengan dirinya dan membutuhkan pertolongan, faktor-faktor diluar diri suasana hati, pencapaian reward pada perilaku sebelumnya dan pengamatan langsung tentang derajat kebutuhan yang ditolong .

${ }^{27}$ Ibid. h. 42 
ISSN (print) : 2442-3217

ISSN (online) : 2716-3806

Homepage : http://journal.iaimsinjai.ac.id/indeks.php/mimbar

\section{Hubungan Sosial}

Dari pengalaman sehari-sehari kita lebih suka menolong teman dekat atau orang-orang yang satu kelompok dengan kita dari pada orang asing atau orangorang yang baru kita temui.

\section{Nilai-nilai Agama dan Moral}

Faktor lain yang mempengaruhi seseorang untuk menolong sanggat tergantung dari penghayatan terhadap nilai-nilai agama dan moral yang mendorong seseorang dalam melakukan pertolongan .

\section{Tanggung Jawab}

Besarnya tangung jawab, hal ini berkaitan dengan kesadaran dalam diri seseorang bahwa dirinya adalah bagian dari sebuah komunitas masyarakat yang mengharuskan dirinya untuk berkerja sama dengan orang lain.

\section{Latar Belakang Keluarga}

Latar belakang keluarga juga sanggat berpengaruh dalam terbentuknya perilaku menolong, seorang anak yang dibesarkan dalam sebuah keluarga yang altruistik tinggi, akan mempengaruhi anak-anak untuk berperilaku altruistik seperti yang didapat di keluarga.

\section{Suasana Hati}

Suasana hati positif (positif mood) dapat mempengaruhi individu dalam perilaku menolong.

\section{Norma Timbal Balik}

Norma timbal balik mengharuskan orang melakukan perbuatan menolong atau membantu dikarenakan rasa balas jasa karena pernah di tolong. ${ }^{28}$

\footnotetext{
${ }^{28}$ Hendri Rain Sus Budiharto, Hubungan antara kecerdasan ruhaniah dengan altruisme, h.
} 54. 
ISSN (print) : 2442-3217

ISSN (online) : 2716-3806

Homepage : http://journal.iaimsinjai.ac.id/indeks.php/mimbar

\section{DAFTAR PUSTAKA}

Agustian, Ari. G, Rahasia Sukses Membagun Kecerdasan dan Spiritual Berdasarkan Rukun Iman dan Rukun Islam, Jakarta: Penerbit Arga, 2001.

Andes, R. Hubungan Antara Kecerdasan Emosional dan Kecerdasan Spiritual dengan Kecenderungan Prilaku Delinkuen pada Remaja pertengahan. Skripsi, t.p., Yogyakarta: fakultas Psikologi Universitas Islam Indonesia, 2004.

Adhim, F.M, Hubungan Antara Orientasi Religius Dan Perilaku Menolong Altruistik Pada Remaja Muslim. Skripsi, t.p., Yogyakarta: Fakultas Psikologi UGM, 2001.

Abdullah, Nashih Ulwan, Pedoman Pendidikan Anak dalam Islam, Jakarta: Asy-yfa', 1993.

Adhim, F.M, Hubungan Antara Orientasi Religius Dan Perilaku Menolong Altruistik Pada Remaja Muslim. Skripsi, t.p., Yogyakarta: Fakultas Psikologi UGM, 2001.

Atkinson, et.al., Pengantar Psikologi, Ed. IIX, Jakarta: Penerbit Erlangga, 1997.

Andrianto, S, Hubungan kematangan Beragama dengan Intensi Prososial pada Mahasiswa Fakulta Psikologi Universitas Islam Indonesia . Skripsi, t.p., Yogyakarta: Fakultas Psikologi UII, 1999.

Atkinson, et.al., Pengantar Psikologi, Ed. IIX, Jakarta: Penerbit Erlangga, 1997.

Andrianto, S, Hubungan kematangan Beragama dengan Intensi Prososial pada Mahasiswa Fakulta Psikologi Universitas Islam Indonesia . Skripsi, t.p., Yogyakarta: Fakultas Psikologi UII, 1999.

Azwar, S, Sikap Manusia; Teori dan Pengukurannya. Yogyakarta: penerbit Liberty, 1990.

, Reliabilitas dan validitas, Cet. VI, Yogyakarta: Pustaka Pelajar Offset, 1997.

Ancok, D. \& F, Nashori, Psikologi Islami : Solusi Islam Atas Problem-problem Psikologi, Yogyakarta: Pustaka Pelajar, 1994. 